\title{
Investigation of Electrodeposited Nano ZnO as a Photoanode for Dye-Sensitized Solar Cell (DSSC)
}

\author{
Theerawut Sumphao* Nattee Khottummee \\ Center of Excellence on Alternative Energy, Research and Development Institute \\ Sakon Nakhon Rajabhat University 680 Nittayo Rd., Mueang District \\ Sakon Nakhon 47000, Thailand
}

\begin{abstract}
This paper reports the deposition and characterization of nanoporous zinc oxide $(\mathrm{ZnO})$ by using a simple and lowcost electrodeposition method. SEM, XRD and UV-Vis are used to study the structural, morphology, and optical properties of $\mathrm{ZnO}$ thin films. $\mathrm{ZnO}$ has a nanosheet-like structure that is $1 \mathrm{~m}$ in size. The optical energy band gap shifts from $3.44 \mathrm{eV}$ to $3.46 \mathrm{eV}$ after the dying process. The organic dye of Clitoria ternatea was extracted and used as a synthesizer. An anthocyanin peak is observed in the absorption spectrum. The zinc oxide films are employed as photoanodes on dye-sensitized solar cells (DSSCs). The I-V characteristic curve parameters show a PCE of $0.027 \%$ and a fill factor of $38 \%$.
\end{abstract}

Keywords: Nano porous zinc oxide, Dye-Sensitized, Electrodeposition

DOI: $10.7176 /$ JETP/10-6-03

Publication date:October $31^{\text {st }} 2020$

\section{Introduction}

Nanostructured zinc oxide $(\mathrm{ZnO})$ has been widely investigated, including its application as a photoanode of dyesensitized solar cells. Many methods are used to deposit $\mathrm{ZnO}$ nanostructures, such as vapor deposition, hydrothermal methods, and spray pyrolysis. Electrodeposition methods have advantages over these methods since they are fast, simple, low cost, and have a low process temperature (Vasekar and Dhakal, 2013). In addition, this method can be used to control the morphology of the grown $\mathrm{ZnO}$ nanostructures (Gong et al., 2010). In previous works, porous nanosheets of $\mathrm{ZnO}$ have been achieved by adding various additives, such as $\mathrm{KNO}_{3}, \mathrm{KBr}_{2} \mathrm{~K}_{2} \mathrm{SO}_{4}$, and $\mathrm{KCl}$, into the electrolyte bath (Hou et al., 2012a, 2012b). However, few studies have reported on the dye absorption of nanoporous $\mathrm{ZnO}$ films. In this research, we focused on the preparation and characterization of nanoporous $\mathrm{ZnO}$, including its application as a photoanode in organic dye-sensitized solar cells. The efficiency of the dye-sensitized solar cells is revealed.

\section{Experimental}

2.1 Preparation of $\mathrm{ZnO}$

$\mathrm{ZnO}$ films were deposited using the following procedures. A commercially available fluorine-doped tin oxide (FTO)-coated glass ( $8 \mathrm{ohm} / \mathrm{square}$ ) was cut into sizes of $3.7 \times 2.0 \mathrm{~cm}^{2}$ and cleaned with soap and then ultrasonicated in acetone solution for 10 minutes. A high purity zinc sheet was cut into the same dimension and well-polished. This sheet is used as the counter electrode. $0.1 \mathrm{M}$ zinc nitrate hexahydrate $\left(\mathrm{Zn}\left(\mathrm{NO}_{3}\right)_{2} \cdot 6 \mathrm{H}_{2} \mathrm{O}\right)$ was used as a source of zinc ions. This precursor was added to $100 \mathrm{ml}$ of deionized water (DI). $0.01 \mathrm{M}$ potassium bromine $(\mathrm{KBr})$ and $0.01 \mathrm{M}$ potassium nitrate $\left(\mathrm{KNO}_{3}\right)$ were used as additives. Deposition was carried out with a laboratory DC power supply in constant current mode at a current density of $-1.0 \mathrm{~mA} / \mathrm{cm}^{2}$ for 20 minutes based on a modified literature method (International Conference on Advanced Materials Processing and Zhang, 2011). The electrolyte bath was kept constant at $65{ }^{\circ} \mathrm{C}$ for all deposition periods. After deposition, the samples were rinsed in deionized water, dried in air and annealed under atmosphere at $250{ }^{\circ} \mathrm{C}$ for 30 minutes.

\subsection{Preparation of redox electrolyte for DSSC}

The redox electrolyte solution was prepared by dissolving $0.5 \mathrm{M}$ potassium iodine $(\mathrm{KI})$ and $0.05 \mathrm{M}$ iodine $\left(\mathrm{I}_{2}\right)$ in $20 \mathrm{ml}$ of ethanol solution (Shelke et al., 2013).

\subsection{Organic dye extraction}

Dye extraction was performed using the following procedures. Five grams of Clitoria ternatea was washed and crushed with $5 \mathrm{ml}$ of deionized water in a plastic bag and then filtered with filter paper to obtain a homogeneous aqueous solution (Ludin et al., 2018).

\subsection{DSSC fabrication}

In brief, zinc oxide on FTO-coated glasses was immersed in organic dye solution for 12 hours and dried at room temperature. Graphite counter electrodes were coated by pencil on FTO-coated glasses. The redox electrolyte solution was dropped onto one surface of the films, sandwiched without using any spacer and fixed with a metal 
clip, as shown in Figure 1. The overall cell dimension is $2.0 \times 3.7 \mathrm{~cm}^{2}$ and the active area for light exposure is 1.0 $\times 1.0 \mathrm{~cm}^{2}$.

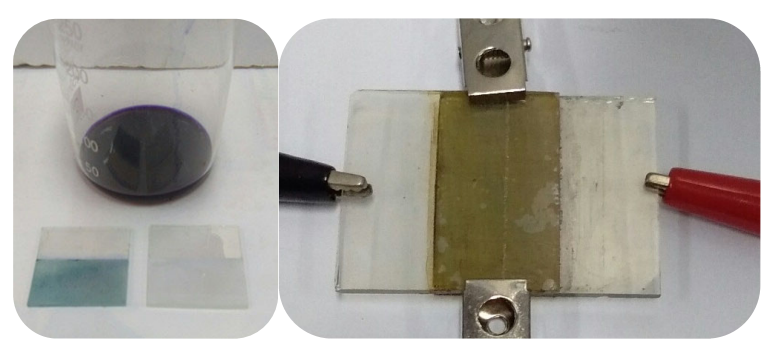

Figure 1. ZnO DSSC Device Fabrication

\subsection{I-V characteristic}

A laboratory-made potentiostat (Dstat) (Dryden and Wheeler, 2015) is used to evaluate the I-V characteristic curves in linear sweep mode at a scan rate of $100 \mathrm{mV} / \mathrm{s}$ under illumination. A high-pressure mercury bulb is used as the light source. The illumination intensity was calibrated by a solar power meter (SM206) at $100 \mathrm{~mW} / \mathrm{cm}^{2}$. The energy conversion efficiency is defined as $\eta=\left(F F \times I_{s c} \times V_{o c}\right) / P_{\text {in }}$, where $P_{\text {in }}$ is the power of the incident light. The fill factor $(\mathrm{FF})$ is defined as $\mathrm{FF}=\left(\mathrm{P}_{\max }\right) /\left(\mathrm{I}_{\mathrm{sc}} \times \mathrm{V}_{\mathrm{oc}}\right)$, where $\mathrm{P}_{\max }$ is the power maximum of the device.

\section{Characterization and measurements}

\subsection{XRD analysis}

The X-ray diffraction pattern of $\mathrm{ZnO}$ films on the FTO substrate is shown in Figure 2. All peaks of $31.7^{\circ}, 34.4^{\circ}$, $36.2^{\circ}, 62.8^{\circ}, 66.3^{\circ}, 76.9^{\circ}, 47.5^{\circ}$ and $56.6^{\circ}$ correspond to the $\mathrm{ZnO}$ wurtzite structure (ICCD PDF\#01-080-0075). In addition, the crystallite size (D) was estimated by applying Debye-Scherrer's equation (Saji et al., 2010), i.e., $\mathrm{D}=k \lambda / \beta \cos \theta$, where $\mathrm{K}$ is the particle shape factor with a value of 0.827 for hexagonal $\mathrm{ZnO}, \beta$ is the full width at half maximum (FWHM) diffraction peak corresponding to the (100) plane, and $\theta$ is Bragg's angle obtained from the $2 \theta$ value corresponding to the same plane. $\lambda$ is the wavelength of $\mathrm{Cu}-\mathrm{K} \alpha$ radiation $(0.15 \mathrm{~nm})$. The average crystallite size of $\mathrm{ZnO}$ is estimated to be $118 \mathrm{~nm}$.

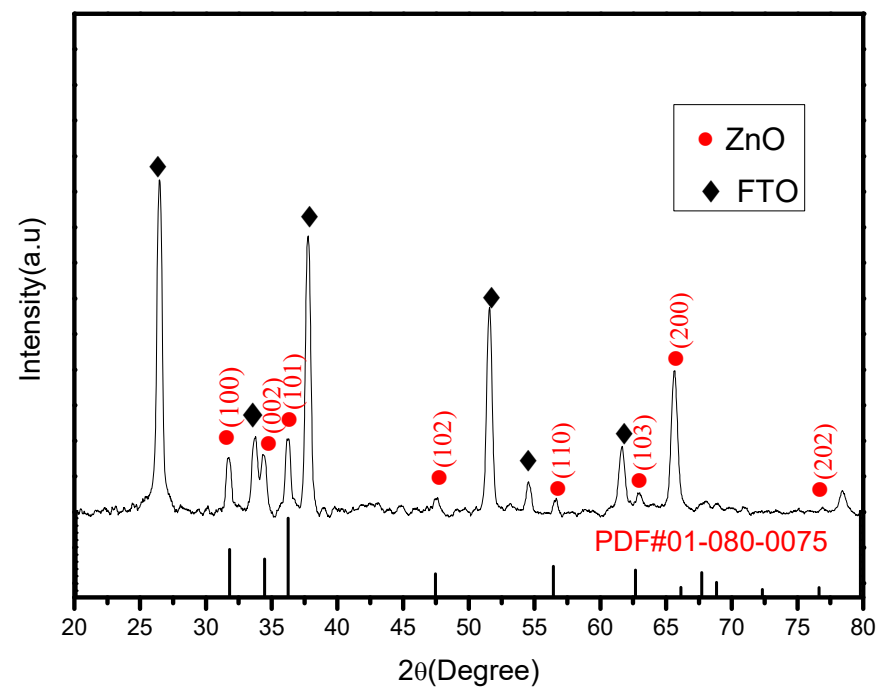

Figure 2. XRD Patterns of $\mathrm{ZnO}$ Films

\subsection{SEM analysis}

Figure 3(a) shows a cross section of $\mathrm{ZnO}$ films. The image confirms high-density vertical growth of $\mathrm{ZnO}$ nanosheets on FTO. The film thickness is approximately 12 microns. The top surfaces of the films shown in Figure 3(b) and Figure 3(d) are relatively smooth, uniform, and interconnected with each other. Figure 3(c) presents a small cluster distributed on the film surface. 

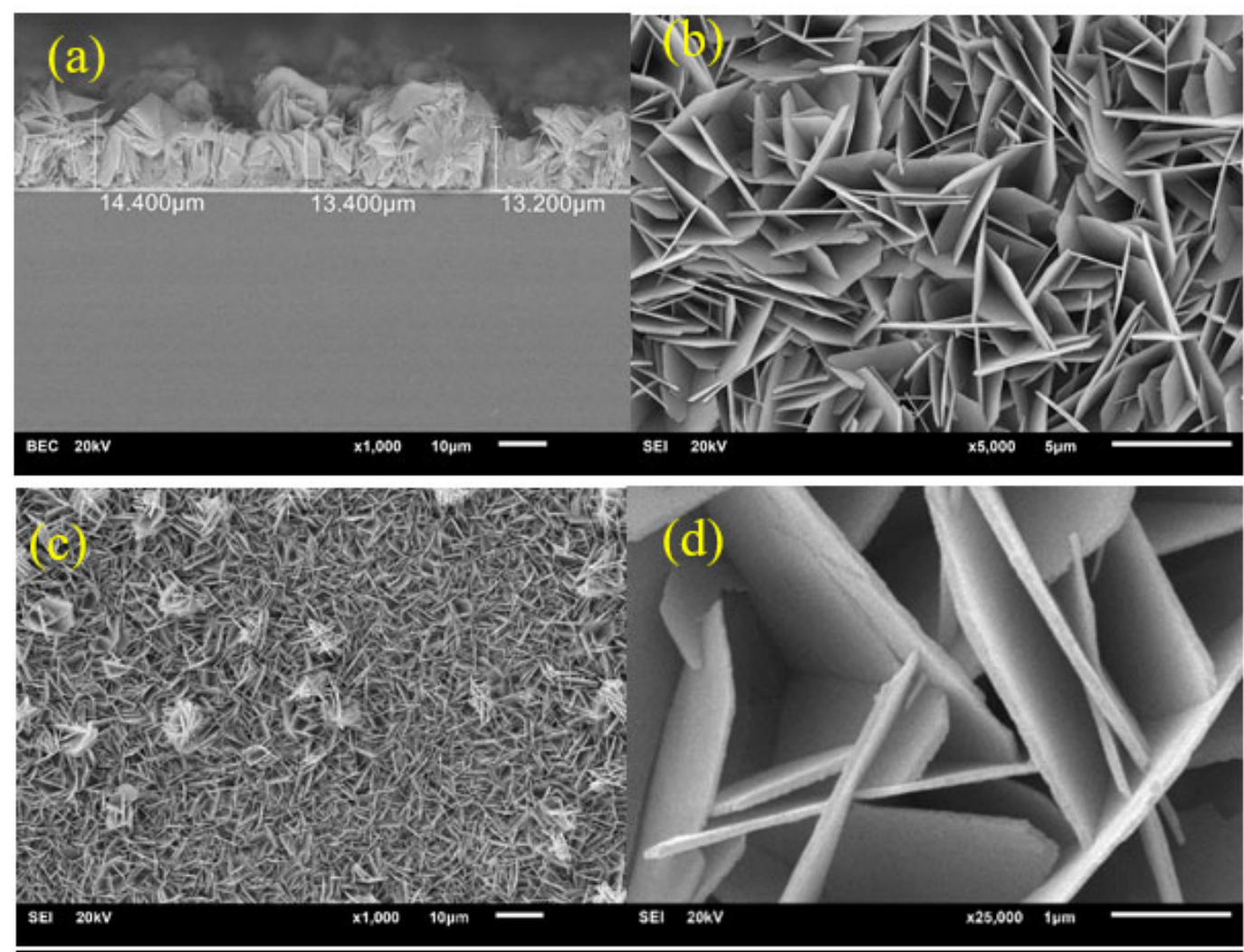

Figure 3. SEM Image of ZnO Films Electrodeposition at $-1.0 \mathrm{~mA} / \mathrm{cm}^{2}$

(a) Cross Section (b) Surface x5000 (c) Surface x1000 and (d) Surface x25000

\subsection{UV-Vis spectral analysis}

$\mathrm{UV}-\mathrm{V}$ is spectroscopy was used to study the absorption of $\mathrm{ZnO}$ before and after the dyeing process. The optical absorption spectrum is shown in Figure 4. The absorption peak centered at $620 \mathrm{~nm}$ confirmed the presence of anthocyanin extracted from Clitoria ternatea flowers in the dyed $\mathrm{ZnO}$ films. The absorption peaks of $\mathrm{ZnO}$ films after the dyeing process have low intensity due to the low chemical bonding between the dye molecule and $\mathrm{ZnO}$ particle. Tauc's equation is used to estimate the optical band gap of the $\mathrm{ZnO}$ films (Ritala and Leskela, 2001), i.e., $\alpha h v=A\left(h v-E_{g}\right) \gamma$, where $\alpha$ is the absorption coefficient, h is Planck's constant, and $v$ is the frequency of light.

Figure 5: the band energy gap of the $\mathrm{ZnO}$ film was calculated by extrapolating the straight portion of the graph on the energy axis in Tauc's plot based on $(\alpha h v)^{2}$ vs. (hv). The optical band gap of $\mathrm{ZnO}$ was shifted from $3.44 \mathrm{eV}$ to $3.46 \mathrm{eV}$ after the dying process, normally found in the absorption of dye on nano metal oxide films.

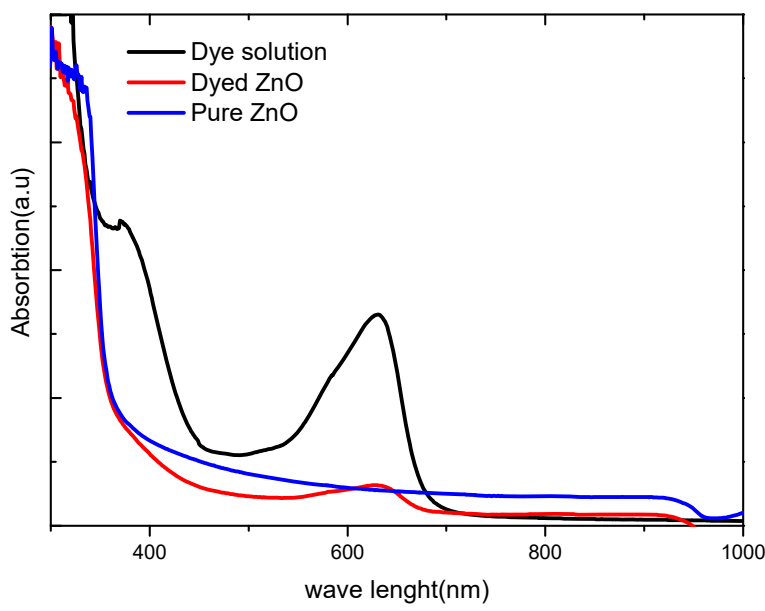

Figure 4. Absorbance Spectrum of the Deposited ZnO Films Before and After Dyeing Process 


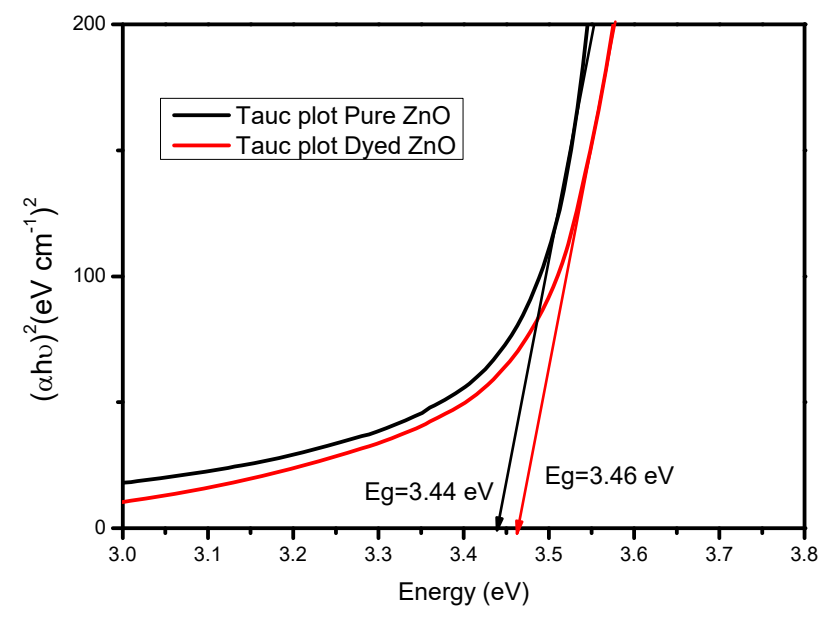

Figure 5. Tauc Plot of The ZnO Film Deposited FTO Substrate

\subsection{I-V characteristic analysis}

Figure 6 shows the photocurrent density-voltage (I-V) curves of $\mathrm{ZnO} /$ graphite DSSCs. Table 1 shows the performance parameters of photocurrent $\left(\mathrm{I}_{\mathrm{sc}}\right)$, open-circuit voltage $\left(\mathrm{V}_{\mathrm{oc}}\right)$, fill factor $(\mathrm{FF})$, and efficiency $(\eta)$ under the testing condition $\left(100 \mathrm{~mW} / \mathrm{cm}^{2}\right)$ compared to the literature. These results revealed that the performance parameters of the DSSC device are in the range of organic dyes.

Table 1. List of literature of DSSCs with $\mathrm{ZnO}$ photoelectrode performance

\begin{tabular}{|c|c|c|c|c|c|c|c|}
\hline $\begin{array}{l}\text { Working } \\
\text { Electrode }\end{array}$ & $\begin{array}{c}\text { Counter } \\
\text { Electrode }\end{array}$ & Dye & $\begin{array}{c}\begin{array}{l}V_{o c} \\
(m V)\end{array} \\
\end{array}$ & $\begin{array}{c}\mathrm{I}_{\mathrm{sc}} \\
(\mathrm{mA})\end{array}$ & FF & $\eta \%$ & Literature Year \\
\hline $\mathrm{ZnO}$ & $\mathrm{Pt}$ & Antocyanin & 233.4 & 0.111 & 0.61 & $0.11 \%$ & Syukron et al. (2014) \\
\hline $\mathrm{ZnO}$ & $\mathrm{Pt}$ & Carica papaya & 373.0 & 0.149 & 0.30 & $0.017 \%$ & Adedokun et al. (2018) \\
\hline $\mathrm{ZnO}$ & $\mathrm{Pt}$ & N719 & 645.0 & 10.40 & 0.56 & $3.75 \%$ & Marimuthu et al. (2018) \\
\hline Zno(nanosheet) & $\mathrm{Pt}$ & N719 & 0.66 & 0.68 & 0.52 & $0.23 \%$ & Moniruddin et al. (2017) \\
\hline $\mathrm{ZnO}$ & Graphite & Antocyanin & 121.3 & 0.58 & 0.38 & $0.027 \%$ & This work \\
\hline
\end{tabular}

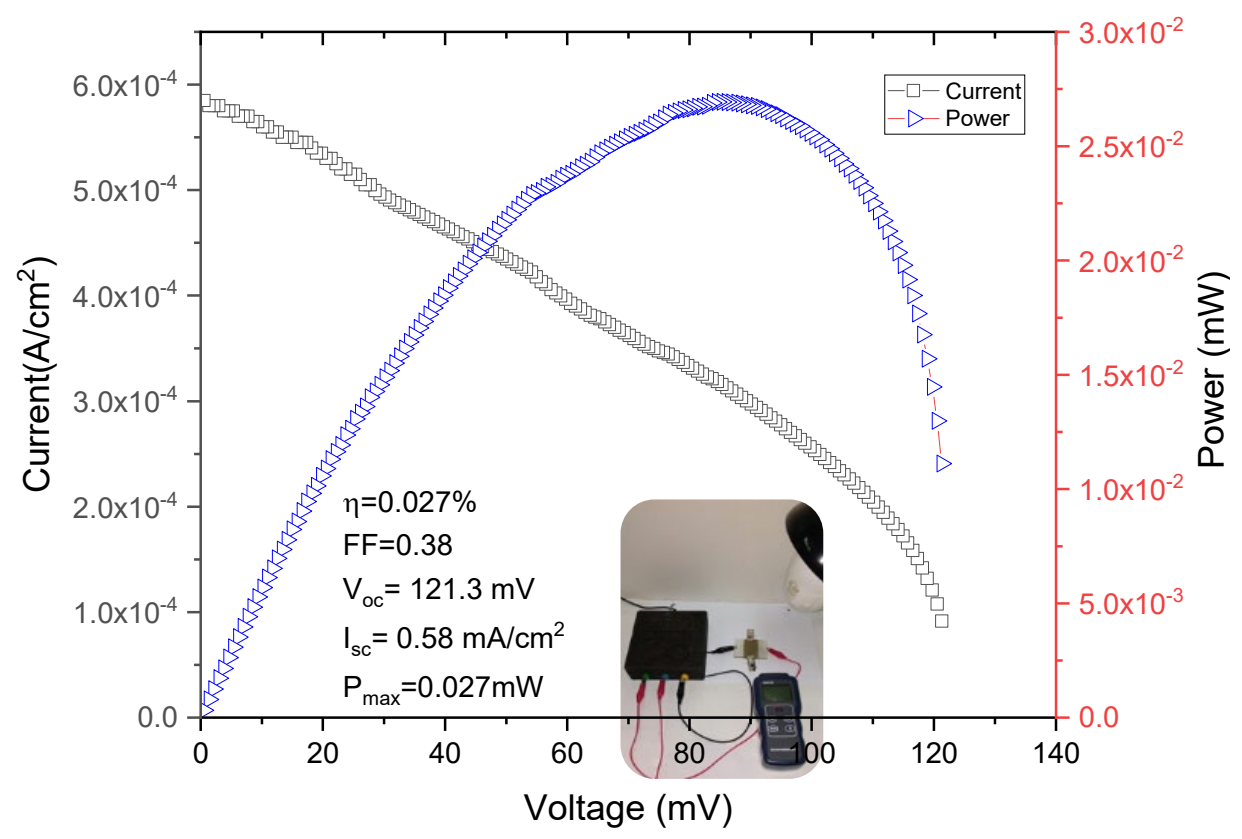

Figure 6. I-V Characteristic of DSSC Device

\section{Conclusions}

In conclusion, $\mathrm{ZnO}$ nanosheets were successfully electrodeposited on FTO glasses via a simple and low-cost two- 
electrode configuration at a current density of $-1.0 \mathrm{~mA} / \mathrm{cm}^{2}$ by introducing $\mathrm{KBr}$ and $\mathrm{KnO}_{3}$ as additives into an electrolytic bath. The analysis of XRD patterns indicates a hexagonal wurtzite structure (ICCD PDF\#01-080-0075), and the crystallite size estimated by the Scherrer equation is $118 \mathrm{~nm}$. The SEM study shows that the surface of the films has a nanosheet-like structure, and is relatively dense, smooth, and uniform. The absorption spectroscopy analysis confirmed the presence of anthocyanin organic dye extracted from Clitoria ternatea flowers. However, the absorption spectra of dyed $\mathrm{ZnO}$ have a low intensity at the peak centered at $620 \mathrm{~nm}$ due to a low bond between $\mathrm{ZnO}$ particles and dye molecules, which leads to a low conversion efficiency of the DSSC device.

\section{References}

Adedokun, O., Awodele, M. K., Sanusi, Y. K., \& Awodugba, A. O. (2018). Natural dye extracts from fruit peels as sensitizer in $\mathrm{ZnO}-$ based dye-sensitized solar cells. IOP Conference Series: Earth and Environmental Science, 173, 012040. https://doi.org/10.1088/1755-1315/173/1/012040

Dryden, M. D. M., \& Wheeler, A. R. (2015). DStat: a versatile, open-source potentiostat for electroanalysis and integration. PLoS One, 10, e0140349. https://doi.org/10.1371/journal.pone.0140349

Gong, J., Dou, Z., Ding, Q., Xu, Y., \& Zhu, W. (2010). Controlled synthesis of ZnO nanostructures by electrodeposition method. Journal of Nanomaterials, 2010, 740628. https://doi.org/10.1155/2010/740628

Hou, Q., Zhu, L., Chen, H., Liu, H., \& Li, W. (2012a). Growth of porous ZnO nanosheets by electrodeposition with the addition of $\mathrm{KBr}$ in nitrate electrolyte. Materials Letters, 89, 283-286. https://doi.org/10.1016/j.matlet.2012.08.137

Hou, Q., Zhu, L., Chen, H., Liu, H., \& Li, W. (2012b). Growth of porous ZnO nanosheets by electrodeposition with $\mathrm{Zn}_{4} \mathrm{SO}_{4}(\mathrm{OH})_{6} \cdot 4 \mathrm{H} 2 \mathrm{O}$ as precursor. Electrochimica Acta, 85, 438-443. https://doi.org/10.1016/j.electacta.2012.08.085

International Conference on Advanced Materials Processing, \& Zhang, Y. F. (2011). Advanced materials and processing 2010. In: Y. Zhang, C. W. Su, H. Xia \& P. Xiao (eds), Proceedings of the 6th international conference on ICAMP 2010, Yunnan, PR China, 19-23 July 2010. Singapore: World Scientific, pp. 360.

Ludin, N. A., Al-Alwani, M. A., Mohamad, A. B., Kadhum, A. A. H., Hamid, N. H., Ibrahim, M. A., Teridi, M. A. M., Al-Hakeem, T. M. A., Mukhlus, A., \& Sopian, K. (2018). Utilization of natural dyes from zingiber officinale leaves and clitoria ternatea flowers to prepare new photosensitisers for dye-sensitised solar cells. International Journal of Electrochemical Science, 13, 7451-7465. https://doi.org/10.20964/2018.08.04

Marimuthu, T., Anandhan, N., \& Thangamuthu, R. (2018). Electrochemical synthesis of one-dimensional ZnO nanostructures on $\mathrm{ZnO}$ seed layer for DSSC applications. Applied Surface Science, 428, 385-394. https://doi.org/10.1016/j.apsusc.2017.09.116

Moniruddin, M., Ilyassov, B., Seliverstova, E., Shabdan, Y., Bakranov, N., Ibrayev, N., \& Nuraje, N. (2017). Bioinspired study of energy and electron transfer in photovoltaic system. Journal of Experimental Nanoscience, 12, 285-296. https://doi.org/10.1080/17458080.2017.1321794

Ritala, M., \& Leskela, M. (2001). Handbook of thin film materials. Deposition and Processing of Thin Films, 1, 103. https://doi.org/10.1016/B978-012512908-4/50005-9

Saji, V. S., Choe, H. C., \& Yeung, K. W. (2010). Nanotechnology in biomedical applications: a review. International Journal of Nano and Biomaterials, 3, 119-139. https://doi.org/10.1504/IJNBM.2010.037801

Shelke, R. S., Thombre, S. B., \& Patrikar, S. R. (2013). Comparative performance of dye Sensitized solar cells using two electrolytes. International Journal for Research in Science \& Advanced Technologies, 3, 131-136. https://doi.org/10.1115/1.4027574

Syukron, A., Wahyuono, R. A., Sawitri, D., \& Risanti, D. D. (2014). The effect of paste preparation and annealing temperature of $\mathrm{ZnO}$ photoelectrode to dye-sensitized solar cells (DSSC) performance. Advanced Materials Research, 896, 183-186. https://doi.org/10.4028/www.scientific.net/AMR.896.183

Vasekar, P. S., \& Dhakal, T. P. (2013). Thin film solar cells using earth-abundant materials. In: A. MoralesAcevedo (ed), Solar cells-research and application perspectives, IntechOpen. 